DOI: $10.36910 / 6775-2524-0560-2020-39-31$

УДК 004.056:33(045)

Ніколіна Ірина Іванівна, канд. наук держ. упр., доцент

https://orcid.org/0000-0001-7718-8599

Гулівата Інна Олександрівна, канд. пед наук, доцент

https://orcid.org/0000-0003-4752-535X

Вінницький торговельно-економічний інституту Київського національного торговельноекономічного університету, м. Вінниця, Україна

\title{
МОДЕЛЮВАННЯ КІБЕРЗЛОЧИННОСТІ ЯК ЗАГРОЗИ ЦИФРОВІЗАЦІЇ ЕКОНОМІКИ
}

\begin{abstract}
Ніколіна І.І., Гулівата І.О. Моделювання кіберзлочинності як загрози цифровізації економіки. Здійснено аналітичний огляд наукових досліджень зарубіжних вчених щодо реалізації тренду цифрової трансформації, методологічного апарату оцінки розвитку цифрової економіки, низки нормативно-правових актів 3 питань цифрових змін в Україні, напрацювань з моделювання окремих ризиків цифровізації економіки. Проведено аналіз наукової літератури щодо специфіки трактування дефініції «цифровізація». Обгрунтовано, що впровадження цифровізації в економіку спричиняє ряд загроз, основна 3 яких є зростання рівня кіберзлочинності. Визначено основні види кіберзлочинів. Змодельовано динаміку головної загрози розвитку цифрової економіки - кіберзлочинність - задля оптимізації управління економічними системами. На основі статистичних даних показано, що темп зростання кіберзлочинності пришвидшиться. Передбачено основні види кіберзлочинів, які нестимуть найбільшу небезпеку. Виявлено, що основними порушеннями з кіберзлочинів $\epsilon$ злочини у сфері платіжних систем. Запропоновано превентивні шляхи діяльності.
\end{abstract}

Ключові слова: цифровізація, цифрова економіка, цифрові технології, кіберзлочинність, моделювання.

Николина И.И., Гуливата И.О. Моделирование киберпреступности как угрозы цифровизации экономики. Осуществлен аналитический обзор научных исследований зарубежных ученых по реализации тренда цифровой трансформации, методологического аппарата оценки развития цифровой экономики, ряда нормативно-правовых актов по вопросам цифровых изменений в Украине, наработок по моделированию отдельных рисков цифровизации экономики. Проведен анализ научной литературы о специфике трактовки дефиниции «цифровизация». Обосновано, что внедрение цифровизации в экономику вызывает ряд угроз, основная из которых является рост уровня киберпреступности. Определены основные виды киберпреступлений. Смоделирован динамику главной угрозы развития цифровой экономики киберпреступность - для оптимизации управления экономическими системами. На основе статистических данных показано, что темп роста киберпреступности ускорится. Предусмотрены основные виды киберпреступлений, которые будут нести наибольшую опасность. Выявлено, что основными нарушениями со киберпреступлений являются преступления в сфере платежных систем. Предложено превентивные пути деятельности.

Ключевые слова: цифровые технологии, Mobile ID, электронная услуга, электронная подпись, идентификация.

Nikolina I., Hulivata I. Modeling cybercrime as a threat to the digitalization of the economy. An analytical review of scientific research of foreign scientists on realization of the digital transformation trend is conducted, as well as on the methodological apparatus for assessing the digital economy development, a series of regulatory acts concerning digital changes in Ukraine and the experience of modelling individual risks of economy digitalization. An analysis of scientific literature on the specifics of the interpretation of the definition "digitalization" is carried out. It is substantiated that the implementation of digitalization into economy creates a number of threats, the main of which is an increase in the level of cybercrime. The main types of cybercrime are defined. The dynamics of the main threat to the digital economy development - cybercrime - are modelled to optimize the management of economic systems. The statistics show that the growth rate of cybercrime will accelerate. The main types of cybercrime that will carry the highest risk are foreseen. It is found that the main violations are crimes in the field of payment systems. Preventive activities are suggested.

Key words: digitalization, digital economy, digital technologies, cybercrime, modelling.

\section{Постановка наукової проблеми.}

Світ вступив у нову епоху цифрової глобалізації, яка визначається безперервними потоками даних, які містять інформацію, знання, ідеї та інновації. Розвинені країни, завершивши індустріалізацію, успішно цифровізують економіки, прискореними темпами розвиваючи цифрові технології, де домінують технології «відкритих даних» (Open Data), «цифрових платформ» (Digital Platform), «блокчейну» (Blockchain) «цифрового робочого місця» (Digital Workplace), «багатоканального інформування та залучення громадян» (Multichannel citizen engagement), «Iнтернет послуг» (IoS), «Кіберфізичні системи» (Cyber-Physical System), «Смарт-факторія» (Smart Factory), «Спільні сервіси 2.0» Shared services 2.0 (Shared services 2.0), штучного інтелекту (AI).

Трансформаційні зміни сучасної України обумовлюються глобальною цифровізацією, яка відображає причинно-наслідковий зв'язок четвертої індустріальної революції («Industry 4.0») та розвитку суспільства («цифрове суспільство»). Масштаб і темп цифрових трансформацій стали основними характеристиками економічного розвитку [12]. 
Реалізація цифрової стратегії розвиту економіки України вимагають від уряду зважених нормативної, організаційно-функціональних складових механізму управління відповідно і до зростання загроз, що спричиняє тотальна цифрова трансформація.

Аналіз досліджень. Питання становлення цифрової економіки, ії наслідки для суспільства й держави, реалізації тренду цифрової трансформації стали об'єктом наукових досліджень зарубіжних вчених, експертів міжнародного індексу оцінки цифрової економіки та суспільства [17-21].

Впродовж попередніх років міжнародними організаціями здійснюється оцінка тих чи інших сегментів цифрової економіки, зокрема, на сьогодні існує достатній методологічний апарат оцінки розвитку цифрової економіки: Digital Economy and Society Index, Digital Evolution Index, The UN Global E-Government Development Index, ICT Dvelopment Index, Networked Readiness Index, E-Participation Index, The Global Innovation Index, Global Connectivity Index.

В Україні питання цифрових змін втілені в розпорядженні КМУ: «Про схвалення Концепції розвитку цифрової економіки та суспільства України на 2018-2020 роки та затвердження плану заходів щодо її реалізації» від 17 січня 2018 № 67-p [12] та постанові КМУ «Деякі питання цифрового розвитку» від 30 січня 2019 р. № 56 [4]. Створення умов для розвитку цифрової економіки закладено у проекті закону «Про цифровий порядок денний України» [16]. В листопаді 2018 р. вступив в дію закон України «Про електронні довірчі послуги», який спрямований на реформування нормативної бази у сфері цифрового підпису, яка уможливлює зростання швидкості розвитку цифрової економіки 3 обов'язковою цифровою партисипацією (digital participation) [11].

Серед вітчизняних науковців досліджуваній проблематиці та загрозам цифровізації приділяли увагу О. Вінник [1], Н. Краус, О. Голобородько та К. Краус [9], В. Ляшенко [12], М. Руденко [13], Н. Ткачук [14], С. Яремко [18]. Питанню моделювання окремих ризиків цифровізації присвячено праці [1, 2, 5-7, 13-16].

Виділення не вирішених раніше частин загальної проблеми. Проте ми вважаємо, що потребує подальшого дослідження питання моделювання загроз цифровізації економіки, зокрема кіберзлочинності.

Мета статті. Головною метою цієї роботи є моделювання проблем, що можуть виникнути в процесі цифрової трансформації, зокрема кіберзлочинності як загрози розвитку цифрової економіки задля оптимізації управління економічними системами.

Виклад основного матеріалу. Диференціація розуміння багатогранності категорії «цифровізація» М. Руденком проявляється у трактуванні цього поняття 3 чотирьох позицій держави, науковців, практиків (підприємців) та суспільства, оскільки визначення вищенаведеного поняття значно видозмінюється в залежності від сфери його застосування, категорії осіб, які давали визначення та кінцевої мети надання [13].

Цифровізація економіки трактується науковцями Т. Юдіною та І. Тушкановим у вузькому та широкому значенні. Зокрема, у вузькому значенні - створення на різних рівнях економіки (глобальному, мега, макро, мезо, мікро, нано) інформаційно-цифрових платформ і операторів, які дозволяють вирішувати різні завдання, у тому числі стратегічні: розвиток медицини, науки, освіти, транспорту, нової індустріалізації, державного регулювання економіки; у широкому сенсі - зміна природи виробничих або економічних відносин, зміну їх суб'єктивно-об'єктивної орієнтованості [177]. Під час цифрової трансформації змінюються виробничі сили суспільства та (або) фактори виробництва [10].

Цифровізація - насичення фізичного світу електронно-цифровими пристроями, засобами, системами та налагодження електронно-комунікаційного обміну між ними, що фактично уможливлює інтегральну взаємодію віртуального та фізичного, тобто створює кіберфізичний простір [12].

Суспільство вбачає у цифровізації абсолютно нову парадигму розвитку держави, основану на повсякденному та повсюдному використанні цифрових технологій 3 обов'язковою наявністю цифрових компетенцій, що забезпечить революційні зміни та становлення цифрового суспільства.

Проведений аналіз наукової літератури дозволяє стверджувати, що специфіка трактування дефініції «цифровізація» обумовлена суб'єктом надання визначення, що спричиняє неоднозначність розуміння досліджуваного поняття та підкреслює дискусійність окремих положень і тверджень.

Цифровізація економіки забезпечує ефективну двосторонню взаємодію держави, суспільства, бізнесу, людини за допомогою цифрових технологій за наявності в усіх учасників комунікації належних цифрових компетенцій. 
Цифрова економіки нерозривно пов'язана з наявністю інформаційного суспільства. В основу терміну «інформаційне суспільство» покладено положення про те, що кількісні зміни у сфері інформації привели до виникнення якісно нового типу соціального устрою - інформаційного суспільства.

Цифровізацію варто розглядати як інструмент, а не як самоціль. При системному державному підході «цифрові» технології будуть стимулювати розвиток відкритого інформаційного суспільства як одного 3 істотних факторів підвищення продуктивності, економічного зростання, створення робочих місць, а також покращення якості життя громадян України [166].

«Цифрові» технології необхідні для зростання ефективності української промисловості, а в деяких секторах вони стають основою продуктових та виробничих стратегій. Їх перетворююча сила змінює традиційні моделі бізнесу, виробничі ланцюжки та обумовлює появу нових продуктів та інновацій. Цифровізація для України носить позитивний соціальний характер, адже зосереджена на поліпшенні якості інфраструктури соціального забезпечення, якості соціальних послуг, організації прозорості та адресності соціальної допомоги, та скорочення витрат [166].

Цифровізація стрімко проникає як в повсякденне життя людей, так і надає нові можливості для всіх секторів економіки України у розрізі модернізації методів роботи та управління, змінюючи виробничі цикли, логістику.

Вагома проблема, яка 3'явилася з початком цифрової трансформації та загострюватиметься 3 часом - кіберзлочинність. Науковці комп'ютерні злочини умовно поділяв на дві основні групи, виходячи 3 класифікаційної ознаки категорії доступу до засобів комп'ютерної техніки: 1) внутрішні користувачі; 2) зовнішні користувачі, де користувач - суб'єкт, який звертається до інформаційної системи, або посередника, за отриманням необхідної йому для користування інформації [5].

Водночас із поширенням використання інтернет-технологій пропорційно зростає й загроза правопорушень, метою яких є хакерські атаки, викрадення персональної інформації, блокування роботи інформаційних служб, шантаж, шахрайство тощо. Це зумовлено низкою причин, зокрема зростанням довіри до електронних засобів обробки інформації, розширенням кола суб'єктів учасників інформаційних відносин у глобальній мережі, збільшенням кількості різноманітних сервісів, переходу до обслуговування банківських установ. В Інтернеті сьогодні набули поширення різноманітні схеми, спрямовані на отримання коштів з недосвідчених і довірливих користувачів інтернет-магазинів, віртуальних аукціонів, сайтів знайомств тощо. Зазвичай для такого виду шахрайства використовуються інтернет-сайти, що візуально та за назвою нагадують відомі міжнародні ресурси. Проте, на відміну від добре зарекомендованих брендів, на отримання замовленого товару або повернення коштів годі й сподіватися. Причина користування такими ресурсами - бажання отримати замовлення за надзвичайно низькою ціною. Іноді зловмисники використовують і протилежні якості людини, наприклад, створюючи фіктивний сайт благодійного фонду або школи-інтернату [5].

3 поширенням технологій змінився і характер злочинів. Якщо раніше більшість 3 них припадала на махінації з пластиковими картками, то тепер відбувається справжній бум у сфері онлайн-платежів. Найбільш професійні хакери вже перейшли у сферу крадіжок через клієнт-банки (системи дистанційного банківського обслуговування). Махінації з картками відходять на другий план, натомість збільшується кількість крадіжок з рахунків компаній або з електронних гаманців [16].

Визначаючи сучасний стан кіберзлочинності в Україні, зауважимо, що вона, як і будь-яке інше соціальне явище, піддається передбаченню за допомогою певних індикаторів, що відбивають іiі кількісні та якісні характеристики. Здійснити таке оцінювання і моделювання можна через аналіз показників поширеності кіберзлочинності в Україні: іiї рівня, географії, структури, динаміки тощо.

Стосовно рівня кіберзлочинності та іiі динаміки зазначимо, що у 2009 р. в України було зареєстровано 217 злочинів у сфері використання електронно-обчислювальних машин (комп'ютерів), систем та комп'ютерних мереж і мереж електрозв'язку, у 2010 р. - 190, у 2011 р. - 131, у 2012 р. 138, у 2013 p. - 595, у 2014 p. - 443, у 2015 p. - 598, у 2016 p. - 865, у 2017 p. - 2573, за січень-серпень 2018 р. - 1885 злочинів (рис. 1). 


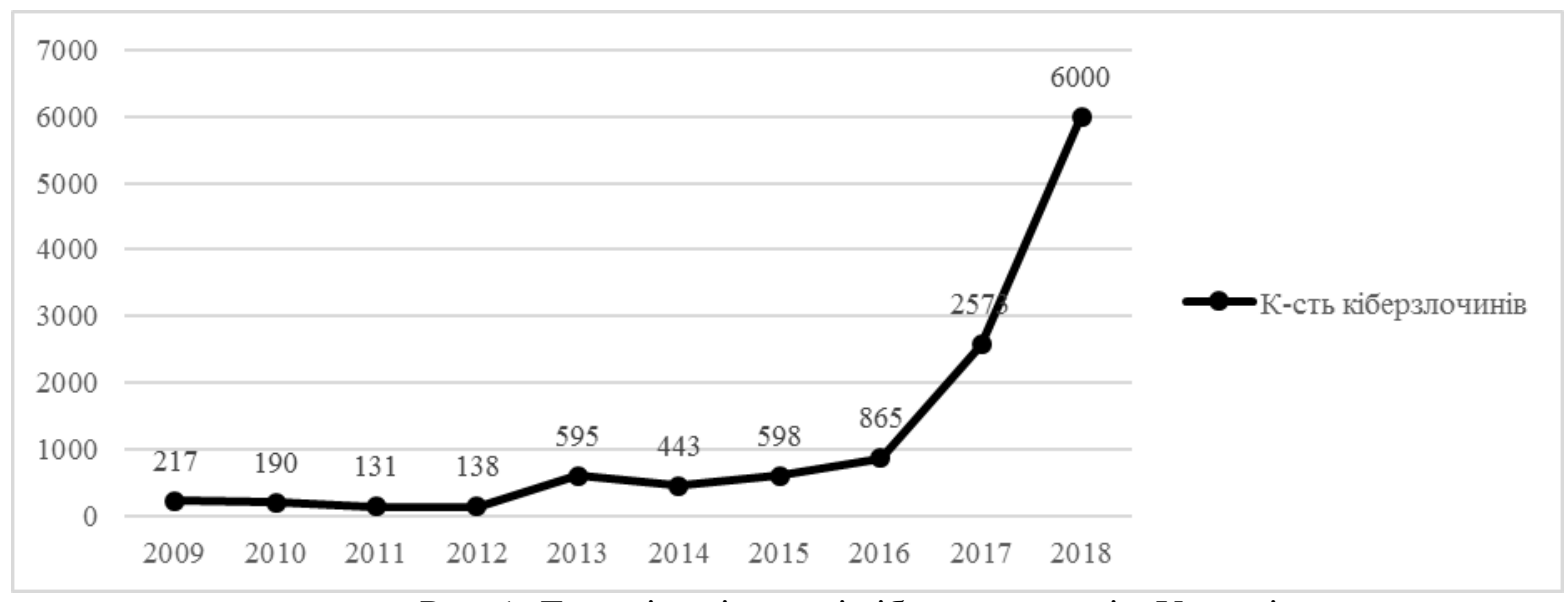

Рис. 1. Динаміка кількості кіберзлочиності в Україні Джерело: розроблено авторами

Питома вага кіберзлочинів у загальній кількості зареєстрованих злочинів становить $0,05 \%$ від загальної кількості зареєстрованих злочинів у 2009 р., $0,04 \%$ - у 2010, 0,03\% - у 2011, 0,03\% - у $2012,0,11 \%$ - у 2013, $0,08 \%$ - у 2014, 0,11\% у - 2015, 0,15\% - у 2016, 0,49\% - у 2017 р. та 0,51\% від злочинів,

зареєстрованих за січень-серпень 2018 р. [8].

Суттєве збільшення кількості зареєстрованих у 2013 р. кіберзлочинів окремі вчені пов'язують із тим, що «зростання вказаного виду злочинності обумовлено щорічним зростанням користувачів Інтернет-ресурсу в Україні» [6].

Як бачимо 3 отриманих статистичних даних по злочинності, кіберзлочини мають значний позитивний приріст (рис. 2).

Наступним не менш важливим кроком $є$ визначення видів кіберзлочинів, які нестимуть найбільшу небезпеку, для цього скористаємось методом АВС-аналізу.

Для розв'язання поставленої проблеми проведемо АВС-аналіз методом «суми» на основі статистичних даних звіту кіберполіції України по кіберзлочинам за 2018 рік.

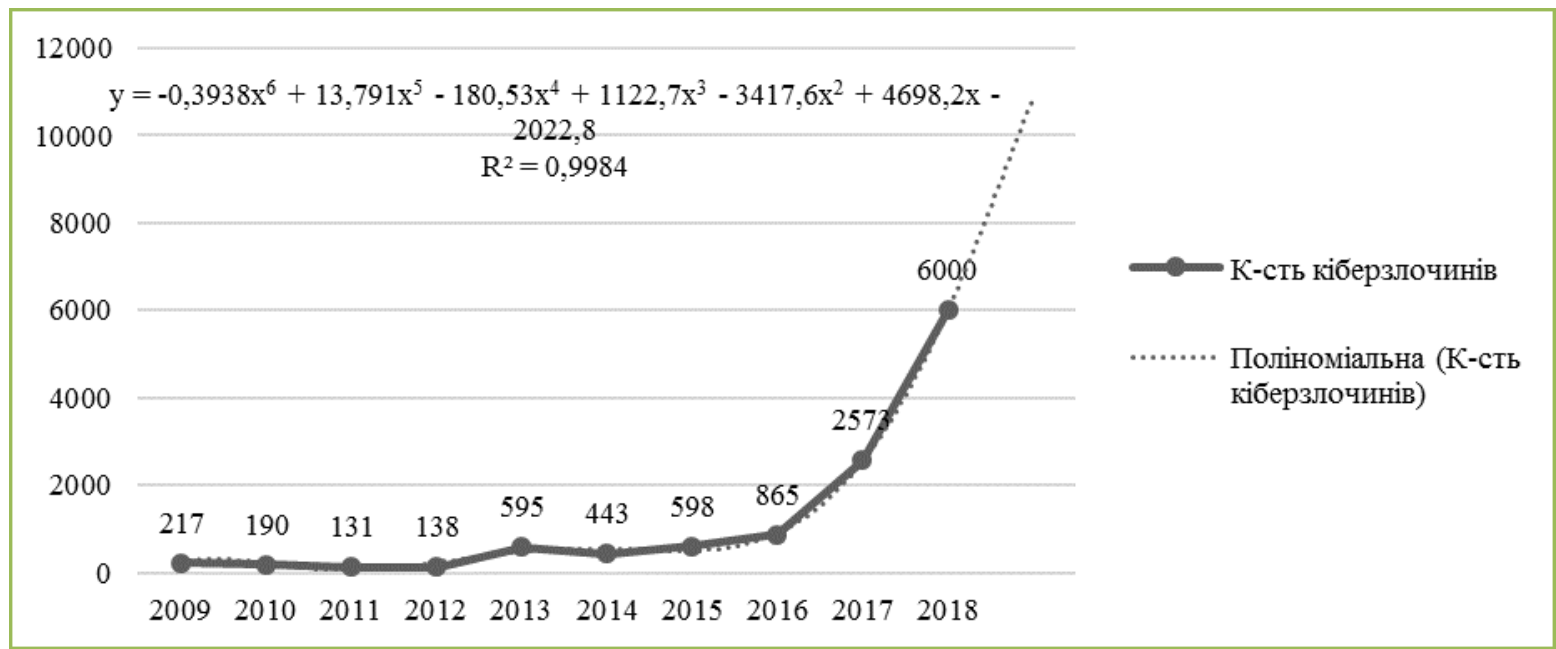

Рис. 2. Прогнозування кіберзлочинності в Україні Джерело: розроблено авторами 
Зведемо результати у таблицю 1.

Таблиця 1. АВС-аналіз кіберзлочинів

\begin{tabular}{|c|c|c|c|c|c|c|}
\hline Кіберзлочин & Кількість & $\begin{array}{l}\text { Частка } \\
\text { фактора у } \\
\text { сумі значень } \\
\text { фактора за } \\
\text { даними [8], } \\
\text { \% }\end{array}$ & $\begin{array}{l}\text { Нароста } \\
\text { юче } \\
\text { значення } \\
\text { ВО, \% }\end{array}$ & $\begin{array}{l}\text { Нароста } \\
\text { юче } \\
\text { значення } \\
\text { ЧО, \% }\end{array}$ & $\begin{array}{l}\text { Сума ЧО } \\
\text { та ВО, \% }\end{array}$ & Група \\
\hline у сфері платіжних систем & 2398 & 39,96000667 & 39,96001 & 25 & 64,96001 & A \\
\hline у сфері е-комерції & 1598 & 26,62889518 & 66,5889 & 50 & 116,5889 & B \\
\hline у сфері кібербезпеки & 1325 & 22,07965339 & 88,66856 & 75 & 163,6686 & B \\
\hline у сфері протиправного контенту & 680 & 11,33144476 & 100 & 100 & 200 & $\mathrm{C}$ \\
\hline
\end{tabular}

На рис. 3 представлена АВС-крива, яка графічно інтерпретує поділ кіберзлочинів на групи.

Узагальнюючи отримані результати, заважимо, що найуразливішою $є$ сфера платіжних систем. Впровадження контрзаходів у ній може зменшити кількість кіберзлочинів майже на $40 \%$ від усіх можливих.

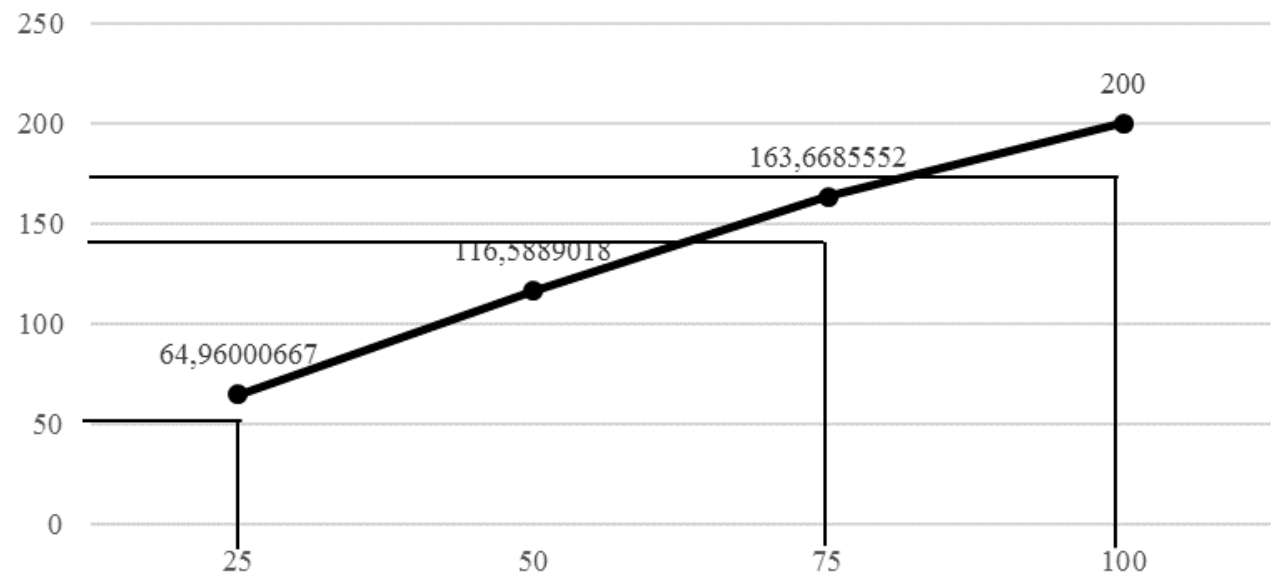

Рис. 3. Графічний результат АBC-аналізу

Джерело: розроблено авторами

Ми вважаємо, що цифровізація економіки збільшить приріст кіберзлочинів. Адже більшість населення, установ, фірм та організацій почнуть переходити на повне цифрове забезпечення, тобто основну інформацію будуть зберігати у цифровому просторі та на серверах.

Уже сьогодні Україна активно бореться з даною проблемою, створено уповноважений орган Кіберполіція України. На даний момент вона виконує такі функції як: реалізація державної політики у сфері протидії кіберзлочинності; завчасне інформування населення про появу новітніх кіберзлочинів; впровадження програмних засобів для систематизації та аналізу інформації про кіберінциденти, кіберзагрози та кіберзлочини; реагування на запити закордонних партнерів, що надходитимуть каналами національної цілодобової мережі контактних пунктів; участь у підвищенні кваліфікації працівників поліції щодо застосування комп'ютерних технологій у протидії злочинності; участь у міжнародних операціях та співпраця в режимі реального часу. забезпечення діяльності мережі контактних пунктів між 90 країнами світу; протидія кіберзлочинам.

На майбутній період пропонуємо удосконалити національну систему кібербезпеки України, щоб вона могла: забезпечити передню лінію оборони проти кіберзагроз шляхом посилення загальної ситуаційної обізнаності щодо інцидентів, вразливостей та загроз у середовищі державних установ, на об'єктах критичної інфраструктури, у громадському сегменті; запобігати вторгненням завдяки обміну інформацією та впровадженням контрзаходів, здатних зменшити поточні вразливості; захищати від повного спектру загроз шляхом підвищення контррозвідувальних та розвідувальних можливостей; зміцнити середовище кібербезпеки через освітянські, медійні громадські ініціативи; стимулювати та забезпечувати проведення кібернавчань, досліджень і розробок у сфері кібербезпеки.

Отже, після проведення нами моделювання впровадження цифровізації в економіку, робимо висновок, що Україна потерпатиме від зростання рівня кіберзлочинності. 
3 тотальною ціфровізацією економіки лише пришвидшить даний темп, так за нашими прогнозами у 2019 році кількість кіберзлочинів може досягти відмітки 9000. Основними 3 яких становлять злочини у сфері платіжних систем (близько 40\%). Тому потрібно покращити заходи безпеки у даній сфері, щоб зменшити рівень кіберзлочинності.

Нагальним залишається і покращення захисту е-комерції та забезпечення кібербезпеки (протидію селерам, кодерам, викрадення баз даних і т.д.).

Висновки і пропозиції. Під час дослідження ми обгрунтували, що впровадження цифровізації в економіку спричиняє ряд проблем та ризиків, основним, на нашу думку, з яких є зростання рівня кіберзлочинності. 3 провадженням цифрових та інформаційних технологій у повсякденне життя та економіку спричиняє поступовий зріст кіберзлочинності, про що свідчать результати наших досліджень. 3 повною цифровізацією економіки лише пришвидшить даний темп. Основними порушеннями з кіберзлочинів $є$ злочини у сфері платіжних систем. Тому потрібно покращити заходи безпеки у даній сфері, щоб зменшити рівень кіберзлочинності.

\section{Список бібліографічного опису}

1. Бойченко О.В. Моделювання сучасних систем захисту інформаційних ресурсів (2009) Вiсник HAУ. №1. URL: http://www.lib.nau.edu.ua/Journals/frmDoc.aspx?param=689.

2. Вінник О. М. Правове забезпечення цифрової економіки та електронного бізнесу. Монографія (2018), 212 с.

3. Гуцалюк M.B. Впровадження ID-web як необхідна умова безпеки в Iнтернет. URL: http://archive.nbuv.gov.ua/portal/soc_gum/bozk/18text/g18_30.htm.

4. Деякі питання цифрового розвитку: постанова Кабінету Міністрів України від 30 січня 2019 р. № 56. URL: https://zakon.rada.gov.ua/laws/show/56-2019-\%D0\%BF.

5. Злочинність в Україні : стат. зб. (2011), 117 с.

6. Книженко О. О. Сучасний стан злочинів у сфері використання електронно-обчислювальних машин (комп'ютерів), автоматизованих систем, комп’ютерних мереж і мереж електрозв'язку в Україні (2014) Бюлетень Міністерства юстииї Украӥни. № 7, С. 122-127.

7. Кононович В., Копитін Ю. Використання АВС аналізу для оптимізації систем захисту інформації (2010) Правове, нормативне та метрологічне забезпечення системи захисту інформації в Україні. Вип. 2 (21), URL: https://ela.kpi.ua/bitstream/123456789/9099/1/21_p26.pdf

8. Кравцова М.О. Сучасний стан і напрями протидії кіберзлочиності в Україні. Вісник кримінологічної асоичіації України. 2018. № 2(19). URL: http://dspace.univd.edu.ua/xmlui/handle/123456789/3848

9. Краус Н.М., Голобородько О.П., Краус К.М. Цифрова економіка: тренди та перспективи авангардного характеру розвитку (2018) Ефективна економіка, №1. URL: http://www.economy.nayka.com.ua/?op=1\&z=6047

10. Ляшенко В.І. Цифрова модернізація економіки України як можливість проривного розвитку: монографія (2018), 252 с.

11. Ніколіна I.І., Ніколіна I.І., Януш М.П. Особливості впровадження та перспективи Моbile ID в Україні (2019) Комп'ютерно-інтегровані технології: освіта, наука, виробнищтво. №34, С.91-95.

12. Про схвалення Концепції розвитку цифрової економіки та суспільства України на 2018-2020 роки та затвердження плану заходів щодо iï реалізації: розпорядження Кабінету Міністрів України від 17 січня 2018 p. № 67p. URL: https://zakon.rada.gov.ua/laws/show/67-2018-\%D1\%80\#n13

13. Руденко М. В. Цифровізація економіки: нові можливості та перспективи (2018) Економіка та держава. № 11. URL: http://www.economy.in.ua/pdf/11_2018/13.pdf

14. Ткачук Н.А. Цифрова грамотність та кібергігієна в Україні (2019) Побудова інформаційного суспільства: ресурси $i$ технологї̈ : матеріали XVIII Міжнародної науково-практичної конференції, Київ, 19-20 вересня 2019 p., 404 с. URL: http://www.uintei.kiev.ua/sites/default/files/materyaly_mon_end.pdf.

15. Україна 2030Е - країна 3 розвинутою цифровою економікою. URL: https://strategy.uifuture.org/kraina-Z-rozvinutoyucifrovoyu-ekonomikoyu.html\#6-2-11

16. Цифрова адженда України - 2020. Концептуальні засади (версія 1.0) (2016), 90 с.

17. Юдина Т.Н. Тушканов И.М. Цифровая экономика сквозь призму философии хозяйства и политической экономии (2017) Философия хозяйства. №1. URL: https://istina.msu.ru/publications/article/56607736/

18. Яремко С. А. Управління інформаційною безпекою корпоративних систем на основі сучасних інформаційних технологій (2012), Економічна кібернетика. №1, С.96-101.

19. Geissbauer R., Vedso J.,. Schrauf S. Industry 4.0: Building the digital enterprise. URL: https://www.pwc.com/gx/en/industries/industries-4.0/landing-page/industry-4.0-building-your-digital-enterprise-april-2016.pdf

20. Schwab K. The Fourth Industrial Revolution (2016), 172 p.

21. The Digital Economy and Society Index (DESI). URL: https://ec.europa.eu/digital-single-market/en/desi.

\section{References}

1. Boichenko O.V. Modeliuvannia suchasnykh system zakhystu informatsiinykh resursiv (2009) Visnyk NAU. №1. URL: http://www.lib.nau.edu.ua/Journals/frmDoc.aspx?param=689.

2. Vinnyk O. M. Pravove zabezpechennia tsyfrovoi ekonomiky ta elektronnoho biznesu. Monohrafiia (2018), $212 \mathrm{~s}$.

3. Hutsaliuk M.V. Vprovadzhennia ID-web yak neobkhidna umova bezpeky $v$ Internet. URL: http://archive.nbuv.gov.ua/portal/soc_gum/bozk/18text/g18_30.htm.

4. Deiaki pytannia tsyfrovoho rozvytku: postanova Kabinetu Ministriv Ukrainy vid 30 sichnia 2019 r. № 56. URL: https://zakon.rada.gov.ua/laws/show/56-2019-\%D0\%BF.

5. Zlochynnist v Ukraini : stat. zb. (2011), $117 \mathrm{~s}$. 
6. Knyzhenko O. O. Suchasnyi stan zlochyniv u sferi vykorystannia elektronno-obchysliuvalnykh mashyn (komp'iuteriv), avtomatyzovanykh system, komp'iuternykh merezh i merezh elektrozv'iazku v Ukraini (2014) Biuleten Ministerstva yustytsii Ukrainy. № 7, S. 122-127.

7. Kononovych V., Kopytin Yu. Vykorystannia ABC analizu dlia optymizatsii system zakhystu informatsii (2010) Pravove, normatyvne ta metrolohichne zabezpechennia systemy zakhystu informatsii $v$ Ukraini. Vyp. 2 (21), URL: https://ela.kpi.ua/bitstream/123456789/9099/1/21 p26.pdf

8. Kravtsova M.O. Suchasnyi stan i napriamy protydii kiberzlochynosti v Ukraini. Visnyk kryminolohichnoi asotsiatsii Ukrainy. 2018. № 2(19). URL: http://dspace.univd.edu.ua/xmlui/handle/123456789/3848

9. Kraus N.M., Holoborodko O.P., Kraus K.M. Tsyfrova ekonomika: trendy ta perspektyvy avanhardnoho kharakteru rozvytku (2018) Efektyvna ekonomika, №1. URL: http://www.economy.nayka.com.ua/?op=1\&z=6047

10. Liashenko V.I. Tsyfrova modernizatsiia ekonomiky Ukrainy yak mozhlyvist proryvnoho rozvytku: monohrafiia (2018), $252 \mathrm{~s}$.

11. Nikolina I.I., Nikolina I.I., Yanush M.P. Osoblyvosti vprovadzhennia ta perspektyvy Mobile ID v Ukraini (2019) Komp'iuternointehrovani tekhnolohii: osvita, nauka, vyrobnytstvo. №34, C.91-95.

12. Pro skhvalennia Kontseptsii rozvytku tsyfrovoi ekonomiky ta suspilstva Ukrainy na 2018-2020 roky ta zatverdzhennia planu zakhodiv shchodo yii realizatsii: rozporiadzhennia Kabinetu Ministriv Ukrainy vid 17 sichnia 2018 r. № 67-r. URL: https://zakon.rada.gov.ua/laws/show/67-2018-\%D1\%80\#n13

13. Rudenko M. V. Tsyfrovizatsiia ekonomiky: novi mozhlyvosti ta perspektyvy (2018) Ekonomika ta derzhava. № 11. URL: http://www.economy.in.ua/pdf/11_2018/13.pdf

14. Tkachuk N.A. Tsyfrova hramotnist ta kiberhihiiena v Ukraini (2019) Pobudova informatsiinoho suspilstva: resursy $i$ tekhnolohii : materialy XVIII Mizhnarodnoi naukovo-praktychnoi konferentsii, Kyiv, 19-20 veresnia 2019 r., 404 s. URL: http://www.uintei.kiev.ua/sites/default/files/materyaly_mon_end.pdf.

15. Ukraina 2030E - kraina z rozvynutoiu tsyfrovoiu ekonomikoiu. URL: https://strategy.uifuture.org/kraina-z-rozvinutoyucifrovoyu-ekonomikoyu.html\#6-2-11

16. Tsyfrova adzhenda Ukrainy - 2020. Kontseptualni zasady (versiia 1.0) (2016), $90 \mathrm{c}$.

17. Yudyna T.N. Tushkanov Y.M. Tsyfrovaia эkonomyka skvoz pryzmu fylosofyy khoziaistva y polytycheskoi $\ni$ konomyy (2017) Fylosofyia khoziaistva. №1. URL: https://istina.msu.ru/publications/article/56607736/

18. Yaremko S. A. Upravlinnia informatsiinoiu bezpekoiu korporatyvnykh system na osnovi suchasnykh informatsiinykh tekhnolohii (2012), Ekonomichna kibernetyka. №1, S.96-101.

19. Geissbauer R., Vedso J.,. Schrauf S. Industry 4.0: Building the digital enterprise. URL: https://www.pwc.com/gx/en/industries/industries-4.0/landing-page/industry-4.0-building-your-digital-enterprise-april-2016.pdf

20. Schwab K. The Fourth Industrial Revolution (2016), 172 p.

21. The Digital Economy and Society Index (DESI). URL: https://ec.europa.eu/digital-single-market/en/desi.

\section{Рецензенти:}

С.А. Яремко - кандидат технічних наук, доцент, доцент кафедри економічної кібернетики та інформаційних систем Вінницького торговельно-економічного інституту КНТЕУ

І.Г. Юник - кандидат наук з державного управління, доцент, доцент кафедри правових наук та філософії Вінницького державного педагогічного університету імені Михайла Коцюбинського 